VERTAISARVIOITU

KOLLEGIALT GRANSKAD

PEER-REVIEWED

www.tsv.fi/tunnus

\title{
KUUROJEN TURVAPAIKANHAKIJOIDEN KIELIKÄSITYKSIEN MUOKKAUTUMINEN TURVAPAIKKAPROSESSIN AIKANA
}

\author{
Nina Sivunen, Soveltavan kielentutkimuksen keskus, \\ Jyväskylän yliopisto
}

\begin{abstract}
Tässä artikkelissa tarkastellaan kahden kuuron turvapaikanhakijan, Monan ja Omarin, kielikäsityksiä haastatteluaineiston pohjalta. Artikkelin tavoitteena on lisätä ymmärrystä siitä, miten turvapaikkaprosessin aikaiset kokemukset kielistä ovat muokanneet haastateltavien käsityksiä kielistä ja kielikäytänteistä. Tutkimus perustuu lingvistiseen etnografiaan teoreettisena ja metodologisena lähestymistapana. Aineisto koostuu kolmesta etnografisesta haastattelusta, jotka tehtiin vuosina 2015-2017 vastaanottokeskuksissa ja haastateltavien uudessa kodissa. Aineisto on analysoitu sisällönanalyysin avulla. Tutkimuksesta selviää, että haastateltavien kielikäsitykset ovat muokkautuneet tilassa, ajassa ja erilaisten arvojärjestelmien ja sosiaalisten käytänteiden, kuten turvapaikkaprosessin, keskellä. Uudet opitut kielet ovat haastateltaville kielellisesti saavutettavampia kuin aiemmat käytetyt kielet ja kielikäytänteet.
\end{abstract}

Avainsanat: kielikokemukset, kielikäsitykset, kuurot turvapaikanhakijat, lingvistinen etnografia, viitotut kielet

\section{JOHDANTO}

Suomeen on saapunut kuuroja turvapaikanhakijoita, joiden kielelliset resurssit ovat heterogeeniset. Suomessa he ovat kokeneet haasteita erilaisissa vuorovaikutustilanteissa, eikä lähtömaassa käytetty kielellinen repertuaari (Blommaert \& Backus, 2013) välttämättä ole toiminut hyvin uudessa kielellisessä ympäristössä (ks. esim. Sivunen, 2019).

Globalisaation ja maahanmuuton myötä puhujat joutuvat uudessa maassa erilaisiin tiloihin (space), joissa on omat kielijärjestel- mät (regime) normeineen, diskursseineen ja kieli-ideologioineen. Nämä uudet kielelliset ympäristöt voivat poiketa suuresti omista totutuista tiloista ja järjestelmistä sekä tutuista kielikäytänteistä ja sosiaalisesta kanssakäymisestä. (Busch, 2017, s. 342-343.)

Nimetyillä kielillä (Gal, 2006) on merkityksellinen asema länsimaisissa yhteiskunnissa historiallisista, poliittisista ja yhteiskunnallisista syistä. Suomeen saapuvilta henkilöiltä, kuten turvapaikanhakijoilta, rekisteröidään

Kirjoittajan yhteystiedot:

Nina Sivunen

nina.j.sivunen@jyu.fi

ninajosivunen@gmail.com 
henkilötietoja, joihin sisältyy myös muun muassa tietoja kielitaidosta (L 1270/1997, 7§), jotta viranomaiset voivat esimerkiksi järjestää turvapaikanhakijalle tulkkauspalvelua henkilön ilmoittamalla äidinkielellä tai sillä kielellä, jota hänen voidaan olettaa ymmärtävän (L 746/2011, 15§). Äidinkielen käsite on kuitenkin aikaisempien tutkimuksien mukaan hämärä ja liukuva, ja ainakin vähemmistöihin kuuluvat voivat kokea sen ongelmallisena (Laihonen \& Halonen, 2019, s. 74; Latomaa \& Suni, 2010). Lisäksi maailmanlaajuisesti tarkasteltuna suurin osa kuuroista ei yleensä nimeä omaa (äidin)kieltään (ks. esim. Moriarty-Harrelson, 2019). Turvapaikanhakijoilla on ulkomaalaislain (L 301/2004, 203\$) mukaan oikeus käyttää kuitenkin vain yhtä omaa kielen tai parhaiten osaamansa kielen tulkkia turvapaikkaprosessissa, mikä viittaa pakolaispolitiikan yksikieliseen kieli-ideologiaan (Maryns, 2006; Määttä, 2015; Pöyhönen \& Simpson, 2020).

Tarkastelen tässä artikkelissa kahden Lähiidästä kotoisin olevan kuuron turvapaikanhakijan kielikäsityksiä haastatteluaineiston pohjalta. Kuurojen turvapaikanhakijoiden turvapaikkaprosessin aikaisia kielikäsityksiä ei ole todennäköisesti aikaisemmin tutkittu. Artikkelin tavoitteena on lisätä ymmärrystä siitä, miten turvapaikkaprosessin aikaiset kieliin liittyvät kokemukset ovat muokanneet haastateltavien käsityksiä kielistä ja heidän kielikäytänteistään. Artikkelin tutkimuskysymyksiä ovat: 1) Miten kuurot turvapaikanhakijat kuvaavat kieliin liittyviä kokemuksiaan turvapaikkaprosessin aikana?2) Miten nämä kokemukset ovat muokanneet heidän käsityksiään kielistä? Artikkelin aineisto koostuu kolmesta etnografisesta haastattelusta, jotka tehtiin vuosina 2015-2017. Seuraavaksi kuvailen tutkimuksen teoreettisen viitekehyksen, minkä jälkeen esittelen tutkimusaineiston, käytetyt tutkimusmenetelmät sekä saadut tutkimustulokset.

\section{TEOREETTISET LÄHTÖKOHDAT}

\subsection{Kielikäsitykset ja kieli-ideologiat}

Tämä osatutkimukseni liittyy sosiolingvistiseen ja sisällönanalyyttiseen tutkimukseen kielikäsityksistä, jotka kuuluvat kieli-ideologiseen tutkimukseen. Kielikäsityksen ja kieli-ideologian käsitteet ovat päällekkäisiä, ja niiden erottaminen voi olla paikoin hankalaa. Mäntynen, Tapionkaski ja Pietikäinen (2018, s. 131) selittävät niiden eroa niin, että kielikäsitysten voidaan nähdä olevan jossain määrin yksilöllisiä ja kieli-ideologiat ovat sen sijaan yhteisöllisiä.

Kieli-ideologioiden tutkimus käsittelee kieleen ja kielenkäyttöön liittyviä käsityksiä, tarkasteluja, neuvotteluja, arvostuksia, toimivuutta, muuttumista ja uskomuksia eri paikoissa ja tilanteissa (Blommaert toim., 1999; Irvine \& Gal, 2000; Woolard, 1998). Kielikäsityksillä taas tarkoitetaan sitä, miten ihmiset käsittävät ja ymmärtävät kielen (Irvine \& Gal, 2000, s. 35; Woolard, 1998, s. 9). Kieli usein ymmärretään soveltavan kielitieteen tutkimuksissa dialogisena ja dynaamisena, jossa kieli käsitetään vuorovaikutuksellisena ilmiönä ja kieli koostuu erilaisista modaliteeteista (viittomisesta, kirjoittamisesta ja puhumisesta) ja resursseista (kielellisistä, semioottisista ja viestinnällisistä) (Dufva, Aro, Suni \& Salo, 2011, s. 24). Kielikäsitys on kollektiivista eli sosiaalista ja vuorovaikutuksellista toimintaa (Varis, 2012, s. 27-32). Tämä tarkoittaa sitä, että vuorovaikutustilanteissa yksilö saa käsityksiä ja kokemuksia itsestään kielenpuhujana eli yksilö kokee ja aistii kehollisesti muilta ihmisiltä, kuka hän on ja millainen hän on kielenkäyttäjänä (Busch, 2017).

Kielikäsitykset ovat kuitenkin luonteeltaan kompleksisia ja dynaamisia, ja ne muokkautuvat ajallisesti, tilanteisesti ja vuorovaikutuksessa ympäristön kanssa (Barcelos \& Kalaja, 
2011, s. 285-286). Aiemmat tutkimukset esimerkiksi osoittavat, että maahanmuuttajien kommunikointikokemukset uudessa kotimaassa ovat olleet useimmiten haastavia ja ne riippuvat useimmiten kieliympäristöistä, sosiaalisista suhteista ja vallasta käyttää kieltä (Márquez Reiter \& Martin Rojo, 2019; Rydell, 2018).

Tässä artikkelissa kielikäsityksillä viittaan haastattelutilanteessa esiin tuleviin ja haastateltavien kertomiin omiin kokemuksiin kielistä ja kielikäytänteistä turvapaikkaprosessin aikana.

\subsection{Viitottujen kielten kieli-ideologia}

Yhteisö viittaa diskursseissaan usein esimerkiksi "omaan kieleen" tai "äidinkieleen" rakentaessaan identiteettiään, statustaan ja hierarkioihin liittyviä konstruktioita (Laihonen \& Halonen, 2019). Kieli- ja kulttuurivähemmistöryhmän jäsenen näkökulmasta vahvan identiteetin ja statuksen rakentuminen on monelle kuurolle useimmiten haastavaa, sillä viittaaminen "omaan kieleen" ei välttämättä ole itsestään selvää. Kuuroihin ja viitottuihin kieliin on kohdistunut ja kohdistuu edelleenkin monenlaisia negatiivisia diskursseja. $\mathrm{Ne}$ vaikuttavat kuurojen elämään ja viitottuihin kieliin liittyviin käsityksiin. (Kusters, Green, Moriarty \& Snoddon, 2020, s. 6-7.)

Kuurojen koulut ovat olleet historiallisesti tarkasteltuna perinteisiä viittomakielten syntypaikkoja, mutta maailman 70 miljoonasta $^{1}$ kuurosta 90 prosenttia ei ole koskaan käynyt koulua (Haualand \& Allen, 2009) ja yli 95 prosenttia kuuroista syntyy kuuleville vanhemmille, joista suurin osa ei välttämättä osaa viitottua kieltä (Mitchell \& Karchmer, 2004). Lisäksi kuuroilla ei välttämättä ole mahdollisuuksia osallistua viittomakieliseen kulttuuriseen ja sosiaaliseen kanssakäymiseen, jossa he voisivat kehittää viitottuihin kieliin liittyvää

\footnotetext{
$\overline{\text { https://wfdeaf.org/who-we-are/ }}$
}

kielitietoisuuttaan ja viittomakielisen identiteettiään. Yhteiskunta saattaa siis olla suljettu esimerkiksi kulttuurin, poliittisen ja sosiaalisen tilanteen vuoksi (Al-Fityani \& Padden, 2010, s. 436; Jaza, 2015).

Suomessa kuten myös monissa muissa maissa viittomakieltä "opetettiin" häpeämään (language shaming, Piller, 2017) ja sen käyttö kiellettiin muun muassa kuurojen opetuksessa vielä 1970-luvulle asti (Salmi \& Laakso, 2005). Viittomakieliin liittyvästä kielihäpeästä pyrittiin irtautumaan länsimaisissa konteksteissa 1970-1980-luvuilla kuurotietoisuusliikkeen ja viittomakielten tutkimuksen myötä (De Meulder, 2016). Maailmalla viittomakieliin liittyvä kielihäpeä ei ole kuitenkaan vielä hävinnyt kokonaan nykypäivän viittomakieliin liittyvistä diskursseista ja kieli-ideologioista (Haualand \& Holmström, 2019), ja se näkyy myös kielteisinä asenteina viitottuja kieliä kohtaan (Krausneker, 2015). Vähemmistökieliä, kuten nimettyjä viitottuja kieliä, pyritään tunnustamaan kansallisella tasolla eri puolilla maailmaa poliittisista syistä (De Meulder, 2016), mikä voidaan nähdä myös kieli-ideologisena toimintana (Kusters ym., 2020, s. 9-11). Maailmassa on edelleen monia dokumentoimattomia viitottuja ja puhuttuja kieliä (De Meulder 2016, s. 31).

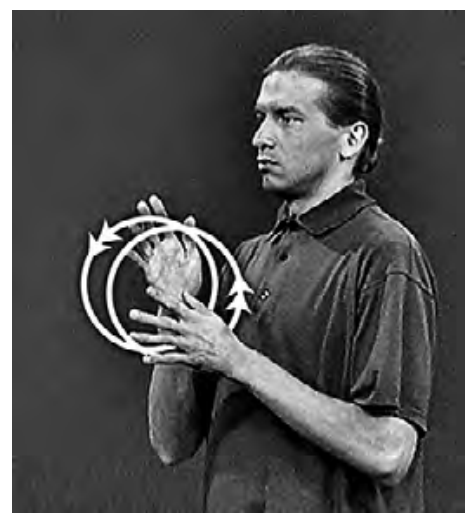

KUVA 1. Viittoa (Suvi, suomalaisen viittomakielen verkkosanakirja: artikkeli 1003. 2013). 
Monissa maissa kuurot, myös suomalaiset kuurot, usein kuvaavat kieltään ja kielikäytänteitään toiminnaksi, jossa kädet ovat läheisessä kontaktissa toisiinsa pyörivää vuoroliikettä tehden (ks. esim. kuva 1). Tämä viittoma ei ole universaali, mutta se on ikoninen ja helposti ymmärrettävissä kaikkialla maailmassa. Esimerkiksi kuurot jordanialaiset kuurot kutsuvat käyttämäänsä viitottua kieltä viittomiseksi (signing) tai kuuroksi arabiaksi (Deaf Arabic) (Hendriks, 2008). Intiassa monet kuurot nimeävät oman kielensä viittomiseksi (signing) eivätkä välttämättä pohdi, onko viittominen kieltä vai eleitä (Kusters \& Sahasrabudhe, 2018). Greenin (2014) tutkimuksessa Nepalissa osa kuuroista viittaa kielenkäyttöönsä/kieleensä termeillä "sign" ja "natural sign", jotka tarkoittavat, että viittominen on luonnollinen osa kommunikointia eikä se rajoitu pelkästään kuurojen vaan myös kuulevien väliseen kommunikointiin. Viittomakielinen yhteisö San Juan Quiahijessa, Oaxacassa, Meksikossa käsittää viitotun kielen käsillä tekemiseksi (making hands) (Hou, 2016). Monet kuurot eri puolilla maailmaa käyttävät jokapäiväisessä kommunikoinnissaan monenlaisia kielellisiä ja semioottisia resursseja, esimerkiksi kotiviittomia, osoituksia ja eleitä. Varsinkaan länsimaiset toimijat eivät ole mieltäneet kehitysmaiden kuurojen käyttämiä kielikäytänteitä niin sanotuiksi oikeiksi kieliksi, minkä vuoksi kuurot usein leimataan kielettömiksi (Moriarty-Harrelson, 2019). Diskurssi siitä, mikä ja milloin (viittoma) kieli on niin sanottua oikeaa kieltä, on kieliideologista (Kusters ym., 2020, s. 12).

\section{TUTKIMUSMENETELMÄT JA EETTISET VALINNAT}

Tutkimukseni perustuu lingvistiseen etnografiaan, joka pyrkii ymmärtämään kieltä sosiaalisena toimintana. Tämä teoreettinen ja metodologinen lähestymistapa näkee kielen kulttuurisena ja tilannekohtaisena konstruktiona. (Creese, 2008; Lehtonen \& Pöyhönen, 2020; Tusting, 2020.) Lingvistisen etnografian keinoin etsitään vastauksia esimerkiksi sellaisiin sosiolingvistisiin kysymyksiin kuin mitä merkityksiä osallistujat antavat vuorovaikutuksessa laajemmille yhteiskuntarakenteille ja millaisia kielellisiä variaatioita niissä on. Tällaisten tutkimuksien tavoitteena on lisätä ymmärrystä kielen sosiaalisesta ulottuvuudesta (Lehtonen \& Pöyhönen, 2020) ja haasteista. Lingvistisessä etnografiassa painotetaan, että laajempien yhteiskuntarakenteiden ja sosiaalisen diversiteetin tarkastelu edellyttää lähempää etnografista havainnointia siitä, miten vuorovaikutus tapahtuu ja miten sitä ylläpidetään monikielisissä konteksteissa (Blommaert \& Rampton, 2016, s. 37-40). Lingvistinen etnografia on myös tiedon keruun, käsittelyn ja analyysin metodologia (Copland \& Creese, 2015). Aineistonkeruussa hyödynnetään etnografisia metodeja, kuten kenttätyötä, haastatteluja ja kenttäpäiväkirjoja. Etnografia ei ole siten vain aineistokeruun metodologia, vaan tutkija tekee jatkuvasti analyysia ja tulkintaa etnografisesta aineistosta sekä itsestään (Blommaert \& Jie, 2010, s. 7-15). Grey ja Piller (2020, s. 66) tähdentävätkin, että etnografi ei ainoastaan kerää aineistoa, vaan hänen on tiedostettava ja reflektoitava kriittisesti omaa tutkijanpositiotaan. Kieli-ideologisia implisiittisiä ja eksplisiittisiä kysymyksiä käsitellään monissa lingvistiseen etnografiaan nojaavissa tutkimuksissa (ks. esim. Kusters \& Sahasrabudhe, 2018; Pöyhönen, Kokkonen \& Tarnanen, 2019).

\subsection{Kentälle pääsy}

Olen etsinyt tutkimukseeni osallistujia lähettämällä sähköposteja 31 vastaanottokeskukseen eri puolille Suomea ja hyödyntämällä sosiaalista verkostoani. Pyysin vastaanotto- 
keskuksen työntekijöitä kysymään, olisivatko kuurot turvapaikanhakijat kiinnostuneita tapaamaan minua ja suostuisivatko he haastatteluun. Kaikkiaan tutkimukseeni osallistui kymmenen kuuroa turvapaikanhakijaa eri puolilla Suomea olevissa kuudessa eri vastaanottokeskuksessa. He kaikki olivat kotoisin Lähi-idästä, ja he olivat saapuneet Suomeen syksyllä 2015. Lisäksi keräsin etnografista tutkimusaineistoa (mm. kenttämuistiinpanot ja haastattelut) kuuroilta turvapaikanhakijoilta, vastaanottokeskuksien työntekijöiltä ja kansanopistossa työskenteleviltä viittomakielenopettajilta vuosina 2015-2017.

Tavatessani kuuroja turvapaikanhakijoita ensimmäisen kerran esittelin itseni ja kerroin olevani tutkija. Haastatteluissa ei ollut mukana Lähi-idän maiden viittomakielten tulkkeja, koska heitä ei ollut Suomessa. Olen tutkijana monikielinen: suomalainen viittomakieli on ensikieleni, ja osaan useita viitottuja ja kirjoitettuja kieliä, sillä olen matkustellut paljon sekä asunut ja työskennellyt muutamissa maissa. En kuitenkaan osaa Lähi-idän maiden viitottuja kieliä enkä tunne esimerkiksi arabialaista kulttuuria. Haastattelin kuuroja turvapaikanhakijoita yhdestä kolmeen kertaan heidän Suomessa oleskelunsa ajan mukaan. Haastattelut kestivät keskimäärin 40 minuuttia. Haastattelujen välissä pidin heihin yhteyttä videopuhelimitse.

Kaikki tutkimukseeni osallistuneet kertoivat käyneensä koulua muutaman vuoden ja saaneensa opetusta oralistisella menetelmällä. Lisäksi he kertoivat, etteivät he osanneet lukea ja kirjoittaa arabian kieltä, joka oli heidän lähtömaidensa virallinen kieli, mutta he kuitenkin tunnistivat ja kirjoittivat muutamia arabiankielisiä sanoja. Vastaanottokeskuksien työntekijöiden haastattelut vahvistavat osallistujieni kertomukset, sillä annettuja arabiankielisiä kirjallisia tiedotteita ja viestilappuja ei ollut ymmärretty. Näiden saamieni tietojen pohjalta päättelin, että kaikilla tutkimukseeni osallistujilla oli alkava ja/tai kehittyvä lukutaito (ks. Opetushallitus, 2017) kirjoitetussa arabian kielessä. Samalla selvisi, että osallistujien viittomakielen taito lähtömaan viitotuissa kielissä vaihteli suuresti. Jotkut osallistujat kertoivat käyttäneensä päivittäisessä kommunikoinnissaan pääasiassa elekieltä ja/ tai kotikieltä. Se on eräänlainen systeemi, jossa ihmiset ovat luoneet viittomia itse omaan käyttöönsä, mutta ne eivät ole laajassa käytössä. Nämä kotiviittomat (homesign) ovat Nystin, Syllan ja Magassouban (2012) mukaan aliarvostettuja, sillä niistä voi kuitenkin kehittyä myöhemmin maan tai alueen virallinen viittomakieli. Osallistujat ovat nimenneet oman lähtömaan viitotun kielen ja kielikäytänteet arabialaiseksi viittomiseksi viittomalla 'arabia viittoa' (Arab Sign ks. Sivunen, 2019), koska heiltä oli todennäköisesti toistuvasti kyselty heidän käyttämäänsä (äidin)kieltä Suomen turvapaikkaprosessin eri vaiheessa. Arabialainen viittominen juontaa juurensa osallistujien lähtömaan valtakieleen, joka on arabia. Lisäksi he usein viittasivat kieleensä 'x siellä viittoa' ( $\mathrm{x}=$ lähtömaa). Huomionarvioista on se, että Lähi-idän arabiankielisissä maissa on pyritty pidemmän aikaa luomaan yhtenäinen arabialainen viittomakieli (ARSL), johon on kerätty ja yhdistetty eri arabiankielisten maiden viittomia. Niin sanottua keinotekoista viitottua kieltä ARSL:ää on levitetty arabiankielisten televisiokanavien kautta, mitä on kritisoitu, koska se voi uhata muiden viittomakielten olemassaoloa arabiankielisissä maissa. (Al-Fityani \& Padden, 2010; Hendriks, 2008; Jaza, 2015.) Kutsun tässä tutkimuksessa osallistujien kieltä arabialaiseksi viittomiseksi. Perustelen valintaani ensinnäkin siten, että he ovat itse viitanneet kieleensä näin, ja toisekseen siten, etten tiedä tarkkaan, mitä muita nimettyjä kieliä he käyttävät kielirepertuaareissaan. 


\subsection{Kenttätyö}

Minulla ja osallistujilla ei ollut yhteistä sujuvaa kieltä. Yhteisen sujuvan kielen puuttuessa viittojat usein käyttävät kommunikointimenetelmää, kuten kansainvälistä viittomista. Kansainvälinen viittominen on itselleni tuttua, ja siksi rohkenin käyttää sitä ensimmäisissä haastatteluissa. Käytin myös muita kieliä (esim. suomalainen viittomakieli, arabialainen viittominen), sekä hyödynsin eleitä ja muita semioottisia resursseja, kuten kuvia ja karttoja.

Kansainvälisen viittomisen ilmiön tarkka määrittely on edelleen vaikeaa, ja se on usein jaoteltu kahteen ryhmään: konventionaaliseen ja spontaaniin. Konventionaalinen kansainvälinen viittominen sisältää pääosin länsimaisia viittomia, ja sitä käytetään monissa erilaisissa kuurojen kansainvälisissä tapahtumissa sekä sosiaalisessa mediassa (Whynot, 2016). Spontaanissa kansainvälisessä viittomisessa sen sijaan kasvokkaisessa vuorovaikutuksessa käytetään enemmän monenlaisia repertuaareja ja semioottisia resursseja hyödyksi jaetussa kontekstissa (Hiddinga \& Crasborn, 2011).

Kaksi jälkimmäistä haastattelua toteutettiin pääosin suomalaisella viittomakielellä, koska osallistujat olivat saaneet suomalaisen viittomakielen opetusta. Haastatteluissa ja kenttätyöskentelyn ohella olin oppinut muutamia arabialaisen viittomisen viittomia ja käyttänyt niitä osallistujien kanssa.

Turvapaikkaprosessi, elämä vastaanottokeskuksissa ja kielikäytänteet ovat tutkimukseni keskeisimpiä konteksteja. Lingvistisen etnografian avulla keskityin siihen, miten tutkimukseen osallistujat kommunikoivat ja käyttävät kieltä vastaanottokeskuksissa sekä omien perheidensä kesken. Vastaanottokeskuksen toimintakulttuuri sekä kieli- ja kommunikointikäytänteet olivat minulle uusia ja tuntemattomia. Lähestyin etnografina itselleni entuudestaan tuntematonta yhteisöä tu- tussa yhteiskunnassa (ks. Copland \& Creese, 2015; Lehtonen \& Pöyhönen, 2020). Säännöllinen kenttätyö vastaanottokeskuksissa on myös tärkeää siksi, että ymmärrän, millaista arkielämä on vastaanottokeskuksessa, mistä tutkimukseen osallistujat puhuvat ja keitä vastaanottokeskuksessa työskentelee tai asuu. Kontekstin ymmärtäminen on tärkeä osa tutkimustyötä (Blommaert, 2001; Blommaert \& Jie, 2010). Kuurot turvapaikanhakijat olivat pääasiassa antaneet vastaanottokeskuksen työntekijöille omia viittomanimiä, jotka esimerkiksi kuvailivat näiden ulkonäköä ja olemusta, esimerkiksi 'pitkä,' 'lyhyt' (pituudeltaan) tai 'silmälasit'. Seurasin kenttätöissä osallistujien arkielämää sekä vuorovaikutustilanteita muun muassa vastaanottokeskuksen työntekijöiden ja asukkaiden välillä. Kenttätöiden aikana havaitsin, että vastaanottokeskuksien ilmapiiri oli usein kireä ja levoton. Se saattoi joskus vaikuttaa haastattelujen kulkuun, sillä osallistujat olivat usein väsyneitä ja apaattisen oloisia.

\subsection{Eettiset kysymykset}

Tutkimukseeni osallistujat ovat kansainvälistä suojelua hakiessaan lain $(\mathrm{L} 87 / 2015,6 \S)$ mukaan haavoittuvassa asemassa, koska heillä on erityistarpeita (fyysinen tila eli tässä tapauksessa kuurous). Lisäksi Euroopan ihmisoikeustuomioistuin on katsonut, että muun muassa vammaiset kuuluvat haavoittuvassa asemassa oleviin ihmisryhmiin ja heidän ihmisoikeuksiensa turvaamiseen vaaditaan erityistoimia. Vammaiset kohtaavat usein ennakkoluuloja ja syrjintää, ja he ovat usein sosiaalisesti ja taloudellisesti heikommassa asemassa verrattuna valtaväestöön (Heikkilä \& Mustaniemi-Laakso, 2019, s. 66). Tutkimukseni osallistujat ovat moniperustaisesti haavoittuvassa asemassa, koska he ovat 1) turvapaikanhakijoita, 2) kuuroja (vammaisia) ja 3) heillä on heikko kieli- ja lukutaito. 
Tutkijan sekä tutkimuksen eettiset velvollisuudet ovat erittäin tärkeitä koko väitöskirjatutkimuksessani. Olen parhaani mukaan pitänyt huolta siitä, että tutkimukseen osallistuminen oli alusta lähtien vapaaehtoista, vaikka minun ja osallistujien välillä ei ollut alussa sujuvaa yhteistä kieltä eivätkä osallistujat ehkä välttämättä ymmärtäneet, mitä tarkalleen olin tutkimassa ja miksi. Jotkut tutkimukseen liittyvät käsitteet olivat osallistujille vaikeita ja abstrakteja selittää ja kuvailla kansainvälisin viittomin tai eleinä, esimerkiksi "tutkija, tutkimus, yliopisto". Sen sijaan kerroin heille, että "kirjoitan isoa kirjaa" ja "saan myöhemmin mustan hatun". Samalla selitin osallistujille, etten ole viranomainen enkä tee päätöksiä, jotka liittyvät heidän turvapaikkahakemuksiinsa. Kerroin myös, että vain minä yksin katson videotallenteita eikä kukaan muu. On mahdollista, että he suostuivat mukaan tutkimukseeni osittain sen vuoksi, että olen viittova ihminen, jonka kanssa he voivat keskustella viittoen. Olen myös hyvin tietoinen tutkijan positiostani ja siitä, että olen etuoikeutetussa asemassa verrattuna osallistujiin. Olen länsimaalainen, valkoinen ja korkeasti koulutettu nainen. Olen viittomakielisen yhteisön jäsen ja aktivisti. Suomalainen viittomakieli on äidinkieleni, ja se on minulle itsestäänselvyys. Olen myös tottunut käyttämään tulkkauspalvelua. Minua ja osallistujia kuitenkin yhdisti muutama asia, kuten kuurous ja siihen liittyvät eletyt kokemukset sekä visuaalis-gesturaalisen modaliteetin käyttö.

Tutkimuslupa laadittiin kuvallisena ja suomen kielellä kirjoitettuna. Kuvallinen tutkimuslupa tarkoittaa sitä, että jokaiseen suostumusta vaativaan kohtaan lisättiin kuvia. Selitin tutkimukseen osallistujille tutkimukseni tavoitteet ja tarkoituksen viittoen mahdollisimman yksinkertaisesti ja tiivistetysti ja käyttäen muun muassa eleitä ja ilmeitä. Useat tutkimusluvassa esiintyvät termit olivat kuitenkin hyvin vaikeita selittää ja kuvailla kansainvälisin viittomin. Tutkimusluvassa olevien kuvien avulla osallistujat kuitenkin ymmärsivät melko hyvin, mitä aioin tehdä tutkimusaineiston avulla. Osallistujat antoivat suostumuksensa viittoen ja samalla rastittivat tutkimusluvassa kuvien vieressä olevia kyllä/ei-ruutuja. Suostumusta tutkimukseen käsiteltiin jokaisella haastattelukerralla, ja tarkensin tutkimukseni tavoitteita etnografisen prosessin edetessä. Näin pystyin varmistamaan, että tutkimukseen osallistujien suostumus perustui mahdollisimman tarkkaan tietoon tutkimuksesta ja että heidän oli mahdollista keskeyttää tutkimukseen osallistumisensa niin halutessaan.

\subsection{Monaja Omar}

Tämän artikkelin osatutkimusaineisto koostuu Lähi-idästä kotoisin olevan turvapaikanhakijapariskunnan, kuuron naisen ja miehen, haastatteluista. Valitsin heidät, koska he olivat käyneet turvapaikkaprosessin alusta loppuun myönteiseen päätökseen asti. Olen haastatellut heitä kolmeen kertaan ja nimeän heidät Monaksi ja Omariksi. He kertoivat käyneensä vain muutaman vuoden koulua, jossa käytettiin oralistista opetusmenetelmää. Molemmat ilmoittivat omaavansa alkavan kielitaidon kirjoitetussa arabian kielessä ja käyttäneensä pääasiassa kotikieltä ja eleitä kommunikointimenetelmänä heidän lähtömaassaan sekä perheen sisällä ennen Suomeen saapumista.

Haastattelut olivat etnografiselle tutkimukselle tyypillisiä keskusteluja, joissa keskityttiin useisiin teemoihin, esimerkiksi Suomeen saapumiseen ja uusien kielten oppimiskokemuksiin. Ensimmäinen haastattelu (48 minuuttia) tehtiin vastaanottokeskuksessa noin kuuden kuukauden päästä heidän saapumisestaan Suomeen. Heidän luonaan vastaanottokeskuksessa oli käynyt muutamia kuuroja vapaaehtoisia, joilta he olivat oppineet joitakin suomalaisia ja kansainvälisiä viittomia. $\mathrm{He}$ 
olivat käyneet muutaman kerran paikallisissa kuurojen yhdistyksissä, joissa he olivat tavanneet muita kuuroja viittovia ihmisiä. Turvapaikkaprosessin aikana he olivat käyttäneet kertomansa mukaan ensimmäistä kertaa elämässään viittomakielen tulkkausta, jonka vastaanottokeskus ja Maahanmuuttovirasto olivat heille tilanneet ja järjestäneet. Keskustelimme haastateltavien taustoista, elämästä kotimaassa ja matkasta Suomeen sekä kommunikointikäytänteistä Suomessa. Toinen haastattelu (30 minuuttia) tehtiin myös vastaanottokeskuksessa noin vuoden kuluttua heidän saapumisestaan Suomeen. Siihen aikaan he olivat aloittaneet suomalaisen viittomakielen opiskelun, ja haastattelu toteutettiin pääosin suomalaisella viittomakielellä. Keskustelimme heidän senhetkisistä kuulumisistaan, suomalaisen viittomakielen oppimisesta sekä kommunikointikokemuksistaan Suomessa. Viimeinen haastattelu ( 58 minuuttia) tehtiin heidän uudessa kodissaan noin puolentoista vuoden kuluttua heidän saapumisestaan Suomeen. Keskustelimme suomalaisella viittomakielellä heidän turvapaikkaprosessistaan, kotoutumisestaan sekä heidän kielenkäytöstään lähtömaassa ja Suomessa. Kolmannessa haastattelussa näytin haastateltaville lyhyitä videopätkiä ensimmäisestä ja toisesta haastattelusta. Haastateltavat kommentoivat katsomisen yhteydessä omia kielikäytänteitään. Haastatteluaineiston esittely ja siihen tutustuminen haastateltavien kanssa on tärkeä osa tutkimusta, ja se lisää muun muassa haastateltavien luottamusta tutkijaan (Rampton, 2020). Haastattelut on tallennettu videotallenteelle. En kysellyt haastatteluissa suoraan heidän käsityksiään kielistä, vaan käsitykset ovat tulleet muutoin esille vuorovaikutuksessa.

\subsection{Aineiston analyysi}

Käytin videokuvatun aineiston käsittelyssä ja analyysissa ELAN-annotaatio-ohjelmaa ${ }^{2}$ (Crasborn \& Sloetje, 2008), jossa viitottuja videoita voi muun muassa helposti tarvittaessa hidastaa ja pysäyttää. Ohjelman avulla litteroin haastatteluaineiston suomen kielelle Word-tekstinkäsittelyohjelmalla. Yhteisen sujuvan kielen puuttuessa en ymmärtänyt joitakin viittomia ja/tai viittomiskokonaisuuksia, ja siksi niitä ei ole käännetty suomen kielelle vaan merkitty kysymysmerkillä. Käännöstekstit ovat omaa tulkintaani ja käännöksiäni. Aineistoa tarkasteltiin aineistolähtöisellä sisällönanalyysillä, jossa analyysiyksiköt valittiin tehtävänasettelun mukaisesti (Tuomi \& Sarajärvi, 2018). Luin suomen kielelle litteroidun aineiston läpi moneen kertaan ja sen lisäksi tarkastelin myös viitottua aineistoa, jotta näkisin, minkälaisia litteroidusta tekstistä puuttuvia kielellisiä tai muita semioottisia resursseja viittomisen lisäksi (esimerkiksi osoituksia, eleitä ja ilmeitä) haastateltavat olivat käyttäneet. Tämän jälkeen karsin aineistosta pois tutkimukselle epäolennaisia asioita ja valitsin analyysiyksikköjä, joissa haastateltavat kertoivat kieliin liittyviä asioita ja kokemuksia. Seuraavaksi ryhmittelin ja teemoittelin aineiston. Olen analysoinut suomenkielistä litteroitua aineistoa laadullisen analyysiohjelman Atlas.ti:n avulla, mutta aineisto on kuitenkin analysoitu pääosin manuaalisesti. Aineistoesimerkit tässä artikkelissa on käännetty suomen kielelle. Käännökset aineistoesimerkeissä eivät kuitenkaan vastaa ja "vangitse kaikkia verbaalisia ja ei-verbaalisia nyansseja täydellisesti" (Nikander, 2010, s. 433), sillä haastateltavat eivät ole viittoneet esimerkiksi seuraavia leksikaalisia viittomia, kuten "kommunikoida" ja "tarkoittaa”. Nämä

\footnotetext{
2 https://tla.mpi.nl/tools/tla-tools/elan/
} 
on kuitenkin käännetty ja merkitty hakasulkeisiin. Tässä artikkelissa en käytä glosseja ja partituureja näyttääkseni, miten haastateltavat ovat asian esittäneet käyttäen erilaisia kielellisiä ja semioottisia resursseja (ks. kuitenkin esim. Sivunen \& Tapio, 2020), koska niillä ei ole merkitystä tässä osatutkimuksessa. Etnografiset kenttähavainnot ja niistä kertyvä tietämys (Blommaert \& Jie, 2010; Lehtonen \& Pöyhönen, 2020) ovat tukeneet myös tätä aineiston analyysiä.

\section{TULOKSET}

\section{1 "Viittoa"}

Haastateltavat viittasivat ja kuvailivat kieli-käsitteen erityisesti turvapaikkaprosessin alussa viittomalla 'viittoa' (ks. kuva 1, luvussa 2.2.), joka kuvaa konkreettista toimintaa.

\section{Esimerkki 1.}

\section{Viittoa, 1. haastattelukerta}

\section{O: Emme osanneet viittoa. \\ 2 M: Me viitoimme huonosti.}

Esimerkissä (1) Omar kertoi, että hän ei osannut ja ymmärtänyt viittomista saapuessaan Suomeen. Hän ei kuitenkaan määrittänyt, mitä viittomakieltä hän tarkalleen tarkoitti, mutta tässä kontekstissa tulkitsin hänen tarkoittavan erityisesti suomalaista viittomakieltä ja kansainvälistä viittomista, joita hän ei ymmärtänyt. Mona jatkoi kommentoimalla, että he viittoivat huonosti. Kolmannella haastattelukerralla, jossa käytettiin suomalaista viittomakieltä, ymmärsin paremmin, mitä Omar ja Mona tarkoittivat sillä, että "he eivät osanneet viittoa" ja "viittoivat huonosti":

\section{Esimerkki 2.}

Eleiden käyttö, 3. haastattelukerta

$1 \mathrm{~N}$ : Miten te olette aikaisemmin kommunikoineet?

2 O: Todella huonosti! [lähtömaassa] emme viittoneet.

3 Kotona me [kommunikoimme vain] elehtien.

$4 \quad$ (koskettaa Monaa, sitten sänkyä ja elehtii nukkua)

5 Tämä [äskeinen tarkoittaa] sänkyä. (elehtii nukkua

6 ja vetää peittoa ylleen)

7 M: (peittää silmiään ja nauraa)

8 N: Miksi naurat? Oliko se hassua?

9 O: (nauraa)

10 M: (peittää silmiään ja nauraa) kyllä kyllä.

11 O: (näyttää elekielellä nukkua ja sitten elehti

12 syömistä) Tämä [tarkoittaa] ruuan keittämistä.

13 M: Niin [se oli tuollaista]! ---

14 O: Emme osanneet viittoa. Tulimme tänne

15 [Suomeen] ja hämmästyin. Viitoin hölmösti. Minua

16 hävetti. En tiennyt. Siellä [vastaanottokeskus] meitä

17 autettiin ja opetettiin viittomaan. He sanoivat, [että] 
18 meidän pitää viittoa! [Mutta] he sanoivat, [että]

19 voimme harjoitella suomen kieltä. Opin

20 [viittomaan] "aiiti" [ja kysyin] mitä se [tarkoittaa].

21 He sanoivat, [että] hän (osoitti Monaa) on äiti.

22 Ahaa! Kysyin, miten isä viitotaan. Se viitottiin näin

23 "isä". Minä olen isä. Täh! Ihmettelin. [Opin myös

24 viittoman kuten] "lapset".

25 M: (peittää silmiään ja nauraa)

26 O: Niin me opimme katsomalla.

27 M: Me molemmat emme osanneet [viittoa]. Voi että!

28 (nauraa)

Yllä olevassa esimerkissä (rivit 3-13) tulee esille, että haastateltavat olivat tottuneet ja kokeneet elehtimisen (ja kotiviittomisen) luonnollisena osana vuorovaikutusta. Kotiviittomat ovat syntyneet vuorovaikutuksissa kuulevien ihmisten kanssa, mikä juontaa juurensa elekielen käytöstä (Crasborn \& Hiddinga, 2011, s. 62). Arabiankielisissä maissa eleet ovat vahva osa viestintää ja kulttuuria (Hendriks, 2008). Haastateltavat kokivat, että heidän käyttämänsä kielellinen repertuaari ei ole oikeaa kieltä eivätkä täten osanneet viittoa (rivi 14). Omar koki viittovansa hölmösti ja häpeävänsä omaa kielikäytäntöään (rivi 15-16), sillä he molemmat olivat saaneet palautetta omasta viittomakielen taidostaan vastaanottokeskuksessa, todennäköisesti kuuroilta vapaaehtoisilta, ja heitä oli kehotettu opiskelemaan suomalaista viittomakieltä (rivit 17-18), mikä on heille tärkeämpää kuin suomen kielen opiskelu (rivi 18-19).

Haastateltavat olivat kokeneet kielellisen repertuaarinsa heikoksi, ja tämä palaute oli muokannut heidän käsitystään aiemmista kielikäytänteistään, kuten kotiviittomisesta ja eleilystä, kielteiseksi. He päätyivät tähän tulkintaan, koska heidän kielellinen repertuaarinsa ei ole toiminut Suomessa "toivotulla tavalla". Kyseinen kieli voi toimia ja olla arvostettu tietyssä paikassa, mutta toisessa paikassa sama kieli voi muuttua ongelmalliseksi ja toimimattomaksi (Pietikäinen, Dufva \& Mäntylä, 2010, s. 20; Moriarty-Harrelson, 2019), ja sama pätee myös kielikäytänteisiin, kuten eleiden käyttöön. Näiden seikkojen vuoksi he kokivat häpeää (Piller, 2017) omia aikaisempia kielikäytänteitään kohtaan.

\subsection{Kansainvälinen viittominen}

Viittoma, kuten "kansainvälinen viittominen" (ks. kuva 2), on toistuvasti käytetty ja viitottu kuuroille turvapaikanhakijoille. Viittoma yhdistetään miltei aina tulkkaustapahtumiin. Suomeen saapuville turvapaikanhakijoille tilataan viittomakielen tulkkausta vastaanottokeskuksen ja maahanmuuttoviraston toimesta (L 746/2011, 15§). Termiä "kansainvälinen viittominen” ei ole välttämättä merkitty kuurojen turvapaikanhakijoiden turvapaikkapuhuttelun pöytäkirjoihin, vaan tulkkauskieleksi merkitään "viittomakieli" (kenttäpäiväkirja 2.5.2016). Tulkkauskieli on ollut suurella todennäköisyydellä kansainvälinen viittominen, josta haastateltavat ovat itse kertoneet. 


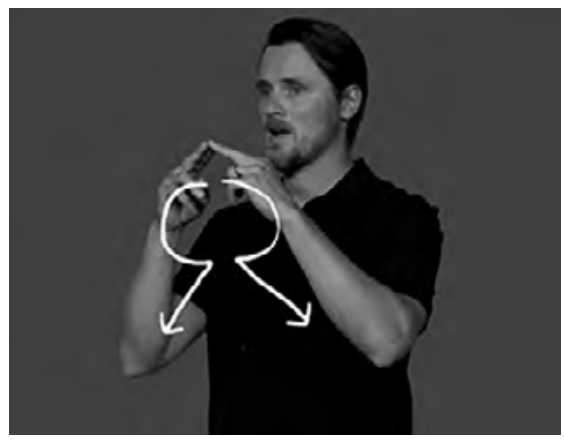

KUVA 2. Kansainvälinen-viittoma (muokattu kuva: viivoja lisätty). Suvi, suomalaisen viittomakielen verkkosanakirja, 2013 (kuva on otettu artikkelin 2260 videosta).

Tulkkaukset ovat Monalle ja Omarille uusia käytänteitä ja kokemuksia. Tulkkaustilanteessa, jossa käytetään kansainvälistä viittomista, käytetään Suomessa useimmiten kahta tulkkia: kuuleva viittomakielen tulkki viittoo suomalaisella viittomakielellä ja kuuro tulkki kääntää sen kansainväliselle viittomiselle. Alla olevassa esimerkissä (3) keskusteltiin tulkkauksesta, jossa käytettiin kansainvälistä viittomista. Olin kiinnostunut siitä, kumpaa kieltä oli heidän mielestään helpompaa ymmärtää: suomalaista viittomakieltä vai kansainvälistä viittomista.

\section{Esimerkki 3.}

\section{Kansainvälinen viittominen,}

\section{2. haastattelukerta}

$1 \mathrm{~N}$ : Kumpaa tulkkia on helpompi ymmärtää?

2 O: Molempia!

3 N: Molempia?

$4 \mathrm{M}$ : [Mutta] kuuleva [tulkki] viittoo nopeasti, en

5 ymmärrä!

6 O: Joo, kuuleva puhuu. [Toinen] kuuleva [tulkki]

viittoo. Kuuro [tulkki] viittoo.
Molemmat [kielet] ovat samoja. Ymmärrän!

Suomalainen [viittomakieli ja] kansainvälinen [viittominen] ovat samoja!

$11 \mathrm{~N}$ : Ahaa.

Kieli-käsite oli haastateltaville edelleen vieras ja abstrakti. Sen vuoksi käytin tulkkikäsitettä (rivi 1), koska se liittyi heidän kommunikointikokemuksiinsa tulkkien kanssa turvapaikkaprosessin aikana. Esimerkistä tuli ilmi, että Mona ja Omar eivät ensi alkuun erottaneet suomalaista viittomakieltä ja kansainvälistä viittomista (rivit 2-3). Mona kuitenkin kommentoi, että kuulevan tulkin viittomista on vaikeampi ymmärtää, ja kokee tulkin viittovan nopeasti (rivi 4-5). Omar jatkaa selittämällä, miten tulkkaus etenee (rivi 6-7), ja toteaa ymmärtävänsä molempia sekä toteaa molempien olevan "samoja" (rivit 8-10). He olivat tottuneet kommunikoinnissa käyttämään kaikenlaisia kielellisiä ja semioottisia resursseja.

Haastateltavat kokivat, että kuuron tulkin viittomista on helpompaa ymmärtää verrattuna kuulevaan tulkkiin. Crasborn ja Hiddiga (2015) selittävät, että kuurojen viittojien yhteisymmärryksen rakentumiseen liittyy jaettu kokemus elää kuurona ihmisenä; kuuron henkilön kommunikointistrategia eli ikonisten viittomien, konstruktioidun toiminnan ja pantomiimin luova käyttö. Lisäksi heillä on taito käyttää eleitä, jotka liittyvät senhetkiseen kontekstiin ja ympäristöön, jossa vuorovaikutus tapahtuu (Sivunen \& Tapio, 2020). Näiden taitojen ja strategioiden vuoksi kuuro tulkki osaa yleensä säädellä viittomisensa vastaanottajalle sopivaksi. Jos viittojat eivät jaa yhteistä kulttuuritaustaa, yhteisymmärryksen rakentuminen voi olla vielä haastavampaa (Hiddinga \& Crasborn, 2011). 
Haastattelussa tuli esille myös, että Mona ja Omar olivat käsittäneet ja kategorisoineet kuurot ja kuulevat henkilöt kielenkäytön modaliteetin perusteella: kuurot viittovat ja kuulevat puhuvat. Alla olevassa esimerkissä (4) he kertoivat ensimmäisestä kohtaamisestaan kuulevan tulkin kanssa:

\section{Esimerkki 4:}

\section{Kuuleva viittova henkilö,}

\section{3. haastattelukerta}

1 O: -- en tiennyt tulkeista. Eräs [tulkki] viittoi minulle.

2 Hämmästyin. Kysyin, oletko kuuro? Hän sanoi, että

3 ei ole. Hän on tulkki.

4 M: (peittää silmiään, nauraa)

5 O: Hän on kuuleva! Hämmästyin! Mitä! Minä en

6 tiennyt. Hän osaa kansainvälistä [viittomista]. Hän

7 sanoi viittovansa kansainvälistä [viittomista].

8 Kysyin, että kansainvälistäkö [viittomista]? Hän

9 sanoi kyllä. Kysyin kuka hän on. Hän sanoi, [että]

10 hän on kuuleva. Tulkki.

Hämmästyin.

11 M: Voi ei! (peittää silmiään, nauraa)

12 O: Minä en tiennyt. Unohdin. Viitoin isosti [ja hitaasti]

13 elehtimällä. En tiennyt. Tulkki kuuntelee ja puhuu.

14 Ottaa minusta mallia. [Näin] se menee. Kuuleva
15 puhuu tulkille. Tulkki kuuntelee. [Hän] viittoo

16 kansainvälistä [viittomista]. Minä näin ja ihmettelin.

17 En tiennyt.

18 M: Kysyin tulkilta, [että] oletko sinä kuuleva? Hän ei

19 ole kuuro. Ei [olekaan]. Hän on kuuleva! Minua

20 nolotti. Me emme tienneet! (nauraa) Pyysimme

21 anteeksi.

22 O: Niin! Emme tienneet! (nauraa) Emme tienneet.

23 Harjoittelemme. Pitää harjoitella.

Omar kertoo, että tulkki-käsite oli hänelle uusi (rivi 1), ja hän hämmästyi, että tulkki on kuuleva (rivit 2-5 ja 10). Haastateltavat eivät erottaneet kuuroa ja kuulevaa viittojaa keskenään. Omar kertoo, että kuuleva tulkki käyttää kansainvälistä viittomista (rivit 6-9). Omar jatkaa, että hän on kommunikoinut kuulevan henkilön kanssa isosti elehtimällä, ennen kuin hänelle selvisi, että kyseinen henkilö onkin tulkki. Omar selittää, miten tulkkaus etenee (rivit 13-16). Kansainvälinen viittominen on heille uusi kommunikointitapa (rivit 16-17). Mona nauraa (rivit 4, 11 ja 20) ja kertoo kysyneensä tulkilta, onko hän oikeasti kuuleva (rivit 18-19). Mona kertoo nolostuneensa ja pahoitelleensa, kun ei tiennyt viittovan henkilön olevan kuuleva (rivit 19-21). Omar nauraa myös ja toteaa, että kuuleva viittova tulkki on heille uusi asia, josta heidän pitäisi oppia (rivit 22-23).

Haastateltavien kokemukset kansainvälisestä viittomisesta tulkkaustilanteen yhtey- 
dessä ovat muokanneet heidän käsityksiään siitä, että kuuleva henkilö (tulkki) voi myös osata viittoa. Kansainvälisen viittomisen voidaan nähdä heidän kokemuksien mukaan olevan sellaista selkokieltä, jossa asia ilmaistaan hitaammin ja tiivistetysti ja sovelletaan viittominen vastaanottajalle sopivaksi.

\subsection{Suomalainen viittomakieli - kielivalinta}

Haastateltaville on annettu suomalaisen viittomakielen opetusta turvapaikkaprosessin aikana. Haastateltavien traumaattiset kokemukset ja muistot lähtömaasta sekä häpeä omista kielikäytänteistään ovat mahdollisesti vaikuttaneet siihen, että arabian kieli ( $j a$ arabialainen viittominen) unohdetaan joko tietoisesti tai tiedostamatta. Alla olevassa esimerkissä (5) Omar kuvailee kokemuksiaan suomalaisen viittomakielen oppimisesta ja arabian kielen unohtamisesta seuraavasti:

\section{Esimerkki 5:}

\section{Oppiminen ja unohtaminen,}

\section{2. haastattelukerta.}

1 O: Olen oppinut ja sisäistänyt suomen [suomalaisen

2 viittoma] kielen. Se on sisälläni. Se on sisälläni. En

3 osaa arabiaa. Vähän vaan. Siellä on paljon (kuvailee

$4 \quad$ kaaosta) [väkivaltaa]. [sen vuoksi] en muista.

$5 \mathrm{~N}$ : Olet unohtanut, joo.

6 O: Täällä on rauhallista. Opin paremmin. Se

7 [suomalainen viittomakieli] on sisälläni kehossani ja

aivoissani. niin.
Omar kertoo opiskelleensa suomalaista viittomakieltä, ja kyseinen kieli on juurtunut sisälle hänen kehoonsa (rivit 1-2). Hän jatkaa, että hän osaa vähän arabian kieltä. Hän kuvaa myös traumaattisia kokemuksiaan lähtömaassaan (rivit 2-4). Tulkitsen (rivi 5), että kysymys on unohtamisesta. Omar jatkaa ja kuvailee, että rauhallisessa ympäristössä oppiminen on helpompaa ja suomalainen viittomakieli on hänen kehonsa sisällä (rivit 6-8). Tulkitsen tämän ilmauksen siten, että suomalainen viittomakieli koetaan ja käsitetään turvallisena ja myönteisenä kielenä, johon ei liity traumaattisia muistoja kuten arabian kieleen. Mielenkiintoista tässä on se, että Omar viittoi "arabia", jolla hän mahdollisesti viittaa kaikkeen kieleen, jota hän on käyttänyt lähtömaassaan (esim. omiin kielikäytänteisiinsä, kuten eleiden ja kotiviittomien käyttöön). Turvapaikkaprosessi aiheuttaa tilannesidonnaista stressiä, ja traumaattiset kokemukset ovat vaikuttaneet haastateltavien muistiprosessiin (ks. Chu, 2011). Pakolaisprosessi on myös poikkeuksellisen voimakas stressitilanne (Ryan, Benson \& Dooley, 2008). Haastateltavien kommunikaatiomahdollisuudet ovat olleet rajattuja lähtöalueella, ja stressitilanne on vaikuttanut siihen, että vähäinenkin arabian kielen taito on unohtunut turvapaikkaprosessin aikana. Alla olevassa esimerkissä (6) haastateltavat kertovat kielivalinnastaan.

\section{Esimerkki 6:}

\section{Kielivalinta, 2. haastattelukerta}

$1 \mathrm{~N}$ : Viitotteko nyt keskenänne suomalaista

2 [viittomakieltä] ja arabialaista [viittomakieltä]

3 sekaisin?

4 O: Ei, vaan suomalaista [viittomakieltä]!

$5 \mathrm{~N}$ : Vain suomalaista [viittomakieltä]? 
6 O: Olemme unohtaneet $\mathrm{x}: \mathrm{n}$ [lähtömaa] [viittomakielen]

7 N: Unohtanut? Entäs sinä? (kysyy Monalta)

8 M: Unohtanut ja heittänyt [arabialaisen viittomisen]

9 pois päästäni!

10 O: Niin [se on tällaista]!

Omar kertoo, että he käyttävät vain suomalaista viittomakieltä (rivi 4) ja ovat unohtaneet lähtömaan kielen (rivi 6). Mona kertoo myös unohtaneensa ja heittäneensä aiemman kielikäytänteen pois päästään (rivit 8-9). Omar vahvistaa asian (rivi 10). He ovat valinneet suomalaisen viittomakielen yhteiseksi kommunikaatiokielekseen. Alla olevassa esimerkissä (7) keskustelu jatkuu:

\section{Esimerkki 7.}

\section{Pieni kieli ja kielivalinta,}

\section{2. haastattelukerta}

1 O: X:ssa [maa] me viitoimme vähän.

2 N: Vähän?

3 O: Kyllä. Vähän. Se oli [semmoista] elehtelyä.

$4 \quad$ Esimerkiksi (elehtii nukkua). Niin [tällä tavoin].

$5 \mathrm{~N}:$ Niin, mutta [miten] te yhdessä [viitoitte]?

6 O: X (viittoma) [tarkoittaa] teetä. Me molemmat

7 [viitoimme] vähän vaan.

$8 \mathrm{~N}$ : Ahaa okei. Te siis viitoitte vähän?
9 O: Niin. Pieni.

$10 \mathrm{M}:$ Kyllä

$11 \mathrm{~N}$ : Viitotte nyt [vain] suomalaista [viittomakieltä]?

12 O: Vahvasti!

$13 \mathrm{M}$ : Vahvasti!

14 N: Tarkoitatteko, että suomalainen viittomakieli on nyt

15 teidän vahva kieli?

16 M: Kyllä, vahva. Se [suomalaisen viittomakielen

17 kielitaito] on mennyt ylöspäin (kuvailee raketin

18 tavoin ylöspäin). Elämä!

Omar kertoo toistuvasti, että he ovat lähtömaassaan viittoneet vähän ja kommunikoivat pääasiassa elekielellä (rivit 1, 3-4 ja 6-7). Omar kuvailee aikaisempaa kieltä pieneksi (rivi 9). Hän tarkoittanee, että hän kokee ja käsittää kotikielen suppeammaksi ja rajoitetummaksi verrattuna heidän oppimaansa uuteen kieleen. Omar ja Mona kertovat, että he käyttävät vain suomalaista viittomakieltä (rivit 12-13). Mona täsmentää, että hänen suomalaisen viittomakielen taitonsa on kehittynyt, ja viittoo lopuksi "elämä" (rivit 16-18).

Monan ja Omarin kielenoppimis- ja kommunikointikokemukset Suomessa ovat muokanneet heidän kielikäsityksiään aikaisempia kieliä kohtaan. Suomalaisen viittomakielen nähdään olevan kielellisesti saavutettavampi, ja he ovat kokeneet kielen olevan "selviytymisen väline" turvapaikkaprosessissa, sillä kyseisellä kielellä he olivat saaneet paljon tietoa monista asioista. 


\section{POHDINTA JA LOPUKSI}

Tutkimukseni tavoitteena oli selvittää, miten turvapaikkaprosessin aikaiset kieliin liittyvät kokemukset ovat muokanneet haastateltavien käsityksiä kielistä ja heidän kielikäytänteistään. Haastateltavat kuvasivat kokemuksiaan kielistä konkreettisina tapahtumina ja vuorovaikutuksellisena ilmiönä (Dufva ym., 2011), kuten nimeämällä kommunikaatiotaan pelkästään viittomalla 'viittoa', joka on itsessään konkreettinen. Turvapaikkaprosessissa vuorovaikutuskokemuksien ja kielitietoisuuden lisääntyessä he oppivat nimeämään kieliä, mutta uudenlaisten resurssien vasta kehittyessä ja niihin liittyvien länsimaisten käsitteiden vierauden vuoksi kansainvälisen viittomisen erottamista nimetyistä viitotuista kielistä ei ole omaksuttu. Suomalaisen viittomakielen opetuksen myötä Omar ja Mona kokivat suomalaisen viittomakielen olevan laajempaa kommunikaatiota mahdollistavaa ja saavutettavampaa kuin heidän käyttämänsä aiemmat kielet ja kielikäytänteet, kuten eleet ja kotikieli. Haastateltavat olivat kategorisoineet aikaisempien vuorovaikutuskokemuksien perusteella kuuron ja kuulevan puhujan kielimodaliteetin perusteella ja käsittäneet, että vain kuurot viittovat ja kuulevat puhuvat.

Haastateltavien kommunikointikokemukset turvapaikkaprosessin aikana olivat muokanneet heidän käsityksiään kielistä. $\mathrm{He}$ kokivat häpeää omia aikaisempia kielikäytänteitään (Piller, 2017) kohtaan, jotka muuttuivat "ongelmallisiksi" heidän saavuttuaan Suomeen. He olivat saaneet palautetta omasta viittomisestaan vastaanottokeskuksessa. Lisäksi lähtömaassa käytettäviin kieliin liittyi traumaattisia muistoja, minkä seurauksena arabian kieli ja arabialainen viittominen haluttiin unohtaa eikä niitä haluttu enää käyttää. Mona ja Omar olivat neuvottelujen sekä vallalla olevien kieli-ideologioiden myötä vaihtaneet kieltä, jotta he voisivat paremmin integroitua uuteen yhteisöön ja tulla hyväksytyiksi yhteisön jäseniksi (Márquez Reiter \& Martín Rojo, 2019).

Tässä tutkimuksessa esitetyt kuurojen turvapaikanhakijoiden kieliin liittyvät kokemukset osoittavat sen, että heidän kielikäsityksensä viitotuista kielistä muokkautui suomalaisen viittomakielen opetuksen ja turvapaikkaprosessissa tapahtuvien vuorovaikutustilanteiden myötä. Kieli käsitteenä oli alkuvaiheessa Monalle ja Omarille vieras ja abstrakti. Kieli, kuten 'viittoa', tarkoitti haastateltaville jotain, mitä tehdään (toimintaa), eikä sitä, mitä omistetaan ("oma kieli") (Bodó, Fazakas \& Imre Heltai, 2017). Haastateltavilla oli erilainen repertuaari ja käsitys kielistä, jotka eivät ole kansallisvaltioiden kieli-ideologioiden mukaisia. Tarkoitan tällä nimettyjen kielten käyttöä ja oman äidinkielen nimeämistä (Bodó, Fazakas \& Imre Heltai, 2017; Gal, 2006), sillä haastateltavien kielirepertuaari koostui kaikenlaisista kielellisistä ja semioottisista resursseista. Haastateltavien kielellä tai pikemminkin kielellisellä repertuaarilla ei ollut "virallista nimeä", vaikka he olivat yrittäneet kuvata omaa kieltään monilla eri tavoilla: 'viittoa,' 'x (lähtömaa) siellä viittoa' ja 'arabialainen viittominen'. Turvapaikkaprosessissa on tärkeää ymmärtää ja tunnistaa kuurojen turvapaikanhakijoiden kielellinen haavoittuvuus (ks. esim. Määttä, Puumala \& Ylikomi, 2020). Tiedetään, että turvapaikkaprosessi edellyttää moninaista vuorovaikutusta viranomaisten kanssa, ja vuorovaikutus on useimmiten monikielistä ja sisältää useiden multimodaalisten ja semioottisten resurssien, esimerkiksi kuvien, eleiden, ilmeiden ja osoitusten, käyttöä (Maryns, 2006; Puumala, Ristimäki \& Ylikomi, 2019). Turvapaikkapuhutteluissa kaikki tulisi sanoa ja ymmärtää oikein, eikä väärinymmärryksiin ole varaa (vrt. Pennycook, 2018). 
Pohdin myös sitä, että kuurot turvapaikanhakijat voidaan mahdollisesti nähdä ja positioida niin sanotuiksi ongelmapuhujiksi (ks. esim. Halonen, 2012): heidän kanssaan kommunikointi tapahtuu yleensä kansainvälisin viittomin, koska yhteistä sujuvaa kieltä ei ole. Kansainvälisen viittomisen käyttö voi mahdollisesti asettaa heidät vielä enemmän haavoittuvampaan asemaan juridisesti. Tämän vuoksi tarvitaan jatkotutkimusta siitä, millaisia kuurojen tulkatut turvapaikkapuhuttelut ovat ja miten niissä otetaan huomioon kuurojen turvapaikanhakijoiden kielelliset oikeudet.

\section{LÄHTEET}

Al-Fityani, K. \& Padden, C. (2010). Sign Languages in the Arab World. Teoksessa D. Brentari (toim.), Sign Languages: A Cambridge survey, (s. 433-450). Cambridge: Cambridge University Press.

Barcelos, A. M. F. \& Kalaja, P. (2011). Introduction to beliefs about SLA revisited. System, 39, 370380.

Blommaert, J. (toim.) (1999). Languageideological debates. Berlin \& New York: Mouton de Gryuter.

Blommaert, J. (2001). Context is/as critique. Critique of Anthropology, 21, 13-32.

Blommaert, J. \& Backus A. (2013). Superdiverse Repertoires and the Individual. Teoksessa I. de Saint-Georges \& J-J. Weber (toim.), Multilingualism and multimodality: Current challenges for educational studies, (s. 11-32). Rotterdam: SensePublishers.

Blommaert, J., \& Jie, D. (2010). Ethnographic fieldwork: A beginner's guide. Bristol: Multilingual Matters.

Blommaert, J. \& Rampton, B. (2016). Language and Superdiversity. Teoksessa K. Arnaut, J. Blommaert, B. Rampton \& M. Spotti (toim.), Language and superdiversity, (s. 21-48). New York: Routledge.

\section{Kiitokset}

Lämpimät kiitokset Suomen Kulttuurirahastoa rahallisesta tuesta artikkelin kirjoittamiseen ja Jyväskylän yliopiston Soveltavan kielentutkimuksen keskukselle tuesta sekä tämän artikkelin anonyymeille arvioitsijoille rakentavista kommenteista ja kannustavasta palautteesta.
Bodó, C., Fazakas, N. \& Imre Heltai, J. (2017). Language revitalization, modernity, and the Csángó mode of speaking. Open Linguistics, 3, 327-341.

Busch, B. (2017). Expanding the notion of the linguistic repertoire: On the concept of Spracherleben - The lived experience of language. Applied Linguistics, 38, 340-358.

Chu, J. A. (2011). Rebuildning shattered lives. Treating complex PTSD and dissociative disorders. New Jersey: Hoboken.

Copland, F. \& Creese, A. (2015). Linguistic ethnography: Collecting, analysing and presenting data. London: Sage.

Crasborn, O. \& Hiddinga, A. (2015). The paradox of international sign: The importance of deaf-hearing encounters for deaf-deaf communication across Sign Language borders. Teoksessa M. Friedner \& A. Kusters (toim.), It's a small world: International deaf spaces and encounters, (s. 59-69). Washington, DC: Gallaudet University Press.

Crasborn, O. \& Sloetjes, H. (2008). Enhanced ELAN functionality for sign language corpora. Proceedings of the $3^{\text {rd }}$ Workshop on the Representation and Processing of Sign Languages: Construction and Exploitation of Sign Language Corpora, 39-43. 
Creese, A. (2008). Linguistic ethnography. Teoksessa K. A. King \& N. H. Hornberger (toim.), Encyclopedia of language and education (2. painos), (s. 229-241). New York: Spinger Press.

De Meulder, M. (2016). The power of language policy. The legal recognition of Sign Languages and the aspirations of deaf commnunities. Publications of the University of Jyväskylä. Dissertations in Jyväskylä Studies in Humanities no 301. Jyväskylä: Jyväskylän yliopisto. http:// urn.fi/URN:ISBN:978-951-39-6876-2

Dufva, H., Aro, M., Suni, M. \& Salo, O-P. (2011). Onko kieltä olemassa? Teoreettinen kielitiede, soveltava kielitiede ja kielen oppimisen tutkimus, AFinLA-E: Soveltavan Kielitieteen Tutkimuksia, 3, 22-34.

Gal, S. (2006). Migration, minorities and multilingualism: Language ideologies in Europe. Teoksessa C. Mar-Molinero \& P. Stevenson (toim.), Language ideologies, policies and practices. Language and globalization, (s. 13-27). London: Palgrave MacMillan.

Green, M. (2014). The nature of signs: Nepal's Deaf Society, local sign, and the production of communicative sociality. $\mathrm{PhD}$ dissertation. Berkeley: University of California.

Grey, A. \& Piller, I. (2020). Sociolinguistic ethnographies of globalization. Teoksessa K. Tusting (toim.), The Routledge handbook of linguistic ethnography, (s. 54-69). New York: Routledge.

Halonen, M. (2012). Rikkinäisiä ja likaisia. Kieli-ideologiset prosessit kielentutkimuksen diskursseissa. Virittäjä, 116, 443-462.

Haualand, H. \& Allen, C. (2009). Deaf people and human rights. Helsinki: World Federation of the Deaf and Swedish National Association of the Deaf.

Haualand, H. \& Holmström, I. (2019). When language recognition and language shaming go hand in hand - sign language ideologies in Sweden and Norway. Deafness \& Education International, 21, 99-115.

Heikkilä, M. \& Mustaniemi-Laakso, M. (2019). Turvapaikanhakijoiden haavoittuvuuden huomioiminen Suomen ulkomaalaisoikeudessa ja -käytänteissä. Teoksessa E. Lyytinen (toim.), Turvapaikanhaku ja pakolaisuus Suomessa, (s. 65-87). Turku: Siirtolaisinstituutti.
Hendriks, B. (2008). Jordanian sign language, aspects of grammar from a cross-linguistic perspective. Utrecht: LOT.

Hiddinga, A. \& Crasborn, O. (2011) Signed languages and globalization. Language in Society, 40, 483-505.

Hou, L.Y.S. (2016). "Making hands": Family sign languages in the San Juan Quiabije community. $\mathrm{PhD}$ dissertation. Austin: University of Texas.

Irvine, J. \& Gal, S. (2000). Language ideology and linguistic differentiation. Teoksessa P. V. Kroskrity (toim.), Regimes of language. Ideologies, polities, and identities, (s. 35-83). Santa Fe, New Mexico: School of American Research Press.

Jaza, Z. (2015). Kurdish Sign Language. Teoksessa J. Bakken Jepsen, G. De Clerck, S. Lutalo-Kiingi $\&$ W.B. McGregor (toim.), Sign Languages of the World. A comparative handbook, (s. 567582). Berlin: De Gryuter Mouton ja Preston: Ishara Press.

Krausneker, V. (2015). Ideologies and attitudes toward sign languages: An approximation. Sign Language Studies, 15, 411-431.

Kusters, A., Green, M., Moriarty, E. \& Snoddon, K. (2020). Sign language ideologies: Practices and politics. Teoksessa A. Kusters, M. Green, E. Moriarty \& K. Snoddon (toim.), Sign Language Ideologies in Practice, s. 3-22. Berlin: De Gryuter Mouton.

Kusters, A. \& Sahasrabudhe, S. (2018). Language ideologies on the difference between gesture and sign. Language \& Communication, 60, 44-63.

L 1270/1997. Laki ulkomaalaisrekisteristä. Haettu 3.11.2020 osoitteesta http://www. finlex.fi/fi/laki/ajantasa/

L 301/2004. Ulkomaalaislaki. Haettu 3.11.2020 osoitteesta http://www.finlex.fi/fi/laki/ ajantasa/

L 746/2011. Laki kansainvälistä suojelua hakevan vastaanotosta sekä ihmiskaupan uhrin tunnistamisesta ja auttamisesta. Haettu 3.11.2020 osoitteesta http://finlex.fi/fi/ ajantasa/

L 87/2015. Laki kansainvälista suojelua hakevan vastaanotosta annetun lain muuttamisesta. Haettu 3.11.2020 osoitteesta http://www. finlex.fi/fi/ajantasa/ 
Laihonen, P. \& Halonen, M. (2019). Vähemmistöt ja enemmistöt kieli-ideologisina käsitteinä. Teoksessa T. Saarinen, P. Nuolijärvi, S. Pöyhönen \& T. Kangasvieri (toim.), Kieli, koulutus, politiikka. Monipaikkaisia käytänteitä ja tulkintoja, (s. 61-90). Tampere: Vastapaino.

Latomaa, S. \& Suni, M. (2010). Toisen sukupolven kielelliset valinnat. Teoksessa T. Martikainen \& L. Haikkola, (toim.), Maahanmuutto ja sukupolvet, (s. 151-174). Helsinki: Suomalaisen Kirjallisuuden Seura.

Lehtonen, H. \& Pöyhönen, S. (2020). Lingvistinen etnografia toimintayhteisöissä. Teoksessa M. Luodonpää-Manni, M. Hamunen; R. Konstenius, M. Miestamo, U. Nikanne \& K. Sinnesmäki (toim.), Kielentutkimuksen menetelmiä 1-4., (s. 345-373). Helsinki: Suomalaisen Kirjallisuuden Seura.

Maryns, K. (2006). The asylum speaker: Language in the Belgian asylum procedure. Manchester \& Northampton: St. Jerome Publishing.

Márquez Reiter, R. \& Martín Rojo, L. (2019). Introduction: Language and speakerhood in migratory contexts. International Journal of Sociology of Language, 257, 1-16.

Mitchell, R.E. \& Karchmer, M. A. (2004). Chasing the mythical ten percent: Parental hearing status of deaf and hard of hearing students in the United States. Sign Language Studies, 4, 138-163.

Moriarty-Harrelson, E. (2019 [2017]). Deaf people with "no language": Mobility and flexible accumulation in languaging practices of deaf people in Cambodia. Applied Linguistic Review, 10, 55-72.

Mäntynen, A., Tapionkaski, S. \& Pietikäinen, S. (2018). Kielikäsitykset vanhustyössä: Asukkaiden, hoitajien ja esimiesten käsityksiä hyvästä vuorovaikutuksesta ja kielenkäytöstä. Puhe ja kieli, 38, 127-151.

Määttä, S. K., Puumala, E. \& Ylikomi, R. (2020). Linguistic, psychological and epistemic vulnerability in asylum procedures: An interdisciplinary approach. Discourse Studies, 00, 1-21.

Määttä, S. K. (2015). Interpreting the discourse of reporting: The case of screening interviews with asylum seekers and police interviews in Finland. Translation \& Interpreting, 7, 21-35.
Nikander, P. (2010). Laadullisten aineistojen litterointi, kääntäminen ja validiteetti. Teoksessa J. Ruusuvuori, P. Nikander \& M. Hyvärinen (toim.), Haastattelun analyysi, (s. 432-445). Tampere: Vastapaino.

Nyst, V., Sylla, K. \& Magassouba, M. (2012). Deaf signers in Douentza, a rural area in Mali. Teoksessa U. Zeshan \& C. de Vos (toim.), Sign Languages in Village Communities. Anthropological and Linguistic Insights, (s. 251-276). Berlin: Mouton de Gruyter.

Opetushallitus (2017). Vapan sivistystyön lukutaitokoulutuksen opetussuunnitelmasuositus. Haettu 24.8.2020 osoitteesta https://www. oph.fi/fi/koulutus-ja-tutkinnot/vapaansivistystyon-lukutaitokoulutuksenopetussuunnitelmasuositus-2017

Pennycook, A. (2018). Applied linguistics as epistemic assemblage. AILA Review, 31, 113134.

Pietikäinen, S., Dufva, H. \& Mäntylä, K. (2010). Monikielisyys liikkeessä: monikielisen perheen kielelliset resurssit. Teoksessa M. Garant \& M. Kinnunen (toim.), AFinLA-e: Soveltavan kielitieteen tutkimuksia, 2, 17-30. Saatavilla: https://journal.fi/afinla/article/view/3873

Piller, I. (2017). Anatomy of language shaming. Language on the Move. Haettu osoitteesta 28.8.2020 https://www.languageonthemove. com/anatomy-of-language-shaming/

Puumala, E., Ristimäki H-L., Ylikomi, R. (2019). Kokemus, kertominen ja tieto turvapaikkamenettelyssä. Teoksessa E. Lyytinen (toim.), Turvapaikanhaku ja pakolaisuus Suomessa, (s. 137-159). Turku: Siirtolaisinstituutti.

Pöyhönen, S., Kokkonen, L. \& Tarnanen, M. (2019). Turvapaikanhakijoiden kertomuksia sosiaalisista verkostoista ja kuulumisen tunteista. Teoksessa E. Lyytinen (toim.), Pakolaisuus Suomessa, (s. 183-204). Turku: Siirtolaisinstituutti.

Pöyhönen, S. \& Simpson, J. (2020). Contesting language policy for asylum seekers in the Northern periphery: The story of Tailor F. Language Policy. https://doi.org/10.1007/ s10993-020-09554-0 
Rampton, B. (2020). Interactional sociolinguistics. Teoksessa K. Tusting (toim.), The Routledge handbook of linguistic ethnography, (s. 13-27). New York: Routledge.

Ryan, D. A., Benson, C. A. \& Dooley, B. A. (2008). Psychological distress and the asylum process: a longitudinal study of forced migrants in Ireland. Journal of Nervous and Mental Disease, 196, 37-45.

Rydell, M. (2018). Being 'a competent language user' in a world of others - Adult migrants' perceptions and constructions of communicative competence. Linguistic and Education, 45, 101-109.

Salmi, E. \& Laakso, M. (2005). Maahan lämpimään. Suomen viittomakielisten historia. Helsinki: Kuurojen Liitto ry.

Sivunen, N. \& Tapio, E. (2020). "Do you understand (me)?" Negotiating mutual understanding by using gaze and environmentally coupled gestures between two deaf signing participants. Applied Linguistic Review, aop, 1-22.

Sivunen, N. (2019). An ethnographic study of deaf refugees seeking asylum in Finland. Societies, 9, 2.

Suvi, suomalaisen viittomakielen verkkosanakirja (2013). Verkkojulkaisu. Helsinki: Kuurojen Liitto ry. Haettu 29.11.2020 osoitteesta http:// suvi.viittomat.net

Tuomi, J. \& Sarajärvi, A. (2018). Laadullinen tutkimus ja sisällönanalyysi (uudistettu laitos). Helsinki: Tammi.

Tusting, K. (2020). General introduction. Teoksessa K. Tusting (toim.), The Routledge handbook of linguistic ethnography, (s. 1-9). New York: Routledge.

Varis, M. (2012). Kielikäsitysyläkoulun äidinkielen oppikirjoissa. Publications of the University of Oulu. Dissertations in Faculty of Education. Oulu: Oulun yliopisto. http://jultika.oulu.fi/ files/isbn9789514299728.pdf

Whynot, Lori A. (2016). Understanding international sign. A sociolinguistic study. Washington, DC: Gallaudet University Press.

Woolard, K. A. (1998). Introduction: Language ideology as a field of inquiry. Teoksessa B. B. Schieffelin, K. A. Woolard \& P. V. Kroskrity (toim.), Language Ideologies. Practice and Theory, (s. 3-47). New York: Oxford University Press. 


\section{DEAF ASYLUM SEEKERS' TRANSFORMATION OF LANGUAGE BELIEFS DURING THE ASYLUM PROCEDURE}

Nina Sivunen, The Centre for Applied Language Studies, University of Jyväskylä

This article examines the language beliefs of two deaf asylum seekers, Mona and Omar, based on the interviews. The goal is to understand how experiences of languages during the asylum procedure has transformed interviewees' beliefs of languages and language practices. This study is based on linguistic ethnography as a theoretical and methodological approach. The data consist of three ethnographic group interviews carried out in 2015-2017 at reception centers and the new homes of the interviewees. The data were analysed using content analysis. This study concludes that interviewees' language beliefs has adapted in middle of a space, time and different value systems and social practices, such as in asylum procedure. Furthermore, it was found that the new learned languages are more linguistically accessible than their previously used languages and linguistic practices.

Keywords: deaf asylum seekers, experiences of languages, language beliefs, linguistic ethnography, signed languages 